\title{
Öğretmen Adaylarının Ölçme Değerlendirmeye Yönelik Tutumlarının Çeşitli Değişkenler Açısından İncelenmesi
}

DOI: $10.26466 /$ opus.755991

*

\section{Serkan Aslan *}

* Dr.Öğr.Üyesi, Süleyman Demirel Üniversitesi, Isparta/Türkiye E-Posta: serkanaslan@sdu.edu.tr

ORCID: $0000-0001-8515-4233$

\section{Öz}

Ölçme-değerlendirme, eğitim sisteminin önemli bir ögesidir. Bu nedenle öğretmenlerin ve öğretmen adaylarının ölçme ve değerlendirmeye yönelik tutumlarını belirlenmesi önem arz etmektedir. Bu araştırmanın temel amacı, öğretmen adaylarının ölçme ve değerlendirmeye yönelik tutumların çeşitli değişkenler açısından incelemektir. Araştırma tarama modellerinden biri olan kesitsel taramaya göre tasarlanmıştır. Araştırmanın çalışma grubunu 241 öğretmen adayı oluşturmuştur. Araştırmanın çalışma grubu ölçüt örnekleme yöntemine göre belirlenmiştir. Araştırmada veri toplama araçlar olarak; kişisel bilgiler formu ile ölçme değerlendirmeye yönelik tutum ölçeği kullanılmıştır. Araştırmanin verileri analiz edilirken betimsel istatistik ile parametrik testlerden olan $t$ testi ve tek yönlü varyans analizi kullanılmıştır. Yapılan analizler neticesinde öğretmen adaylarının ölçme değerlendirmeye yönelik tutumlarına katılım düzeyleri yüksek çıkmıştır. Ayrıca araştırma sonucunda öğretmen adaylarının ölçme değgrlendirmeye yönelik tutumları arasında cinsiyet, öğrenim görülen bölüm, üniversiteye giriş puan türleri ve ölçme-değerlendirme dersini yeterli bulma değişkenleri arasında anlaml farklılık elde edilirken, öğrenim görülen sını düzeyi ve akademik başarı değişkenleri açısından anlaml farklılık elde edilmemiştir. Araştırmanın sonuçlarına dayalı olarak çeşitli öneriler geliştirilmiştir.

Anahtar Kelimeler: Tutum, ölçme, değerlendirme, öğretmen adayı. 


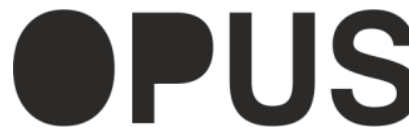

Uluslararası Toplum Araştırmaları Dergisi International Journal of Society Researches
E-ISSN : 2528-9535

YIl Year: 10

Cilt Volume: 16

Sayı Issue :Eğitim ve Toplum Özel Sayısı

Aralık December 2020

Makalenin Geliş Tarihi Received Date: 21/06/2020

Makalenin Kabul Tarihi Accepted Date: 29/12/2020

\title{
An Investigation Of Prospective Teachers Attitudes For Measurement Assessment In Terms Of Various Variables
}

\begin{abstract}
Measurement-evaluation is an important element of the education system. Therefore, it is important to determine the attitudes of teachers and prospective teachers towards measurement and evaluation. The main purpose of this research is to examine the attitudes of prospective teachers towards measurement and evaluation in terms of some variables. It was designed for cross-sectional survey model, which is one of the research survey models. The study group of the research consisted of 241 prospective teachers. The study group of the research was determined according to the criterion sampling method. In the research, personal information form and attitude scale towards measurement and evaluation were used as data collection tools. While analyzing the data of the research, descriptive statistics, $t$ test and one-way analysis of variance, which are parametric tests, were used. As a result of the analysis, the level of participation of prospective teacher in their attitudes towards measurement and evaluation was high. In addition, as a result of the research, while there was a significant difference between the attitudes of prospective teachers towards measurement and evaluation in terms of gender, department of education, types of university entrance score, and finding the assessment-evaluation course sufficient, there was no significant difference in terms of grade level and academic achievement variables.
\end{abstract}

Keywords: Attitude, measurement, evaluation, prospective teacher. 


\section{Giriş}

Günümüzde eğitimin temel amaçlarından biri, bireylerin üst düzey düşünme becerilerine sahip olmasını sağlamak ve çağın gereklerine uygun bireyler yetiştirmektir. $\mathrm{Bu}$ amacın gerçekleştirilebilmesi için de bireylerin çağın gereklerine ve üst düzey düşünme becerilerine sahip olup olmadıkları belirlenmelidir. Bunun için de eğitim sisteminin önemli bir ögesi olan ölçme ve değerlendirme sürecinin etkili yürütülmesi gerekmektedir.

Ölçme ve değerlendirme tüm eğitim sistemlerinin vazgeçilmez bir unsurudur. Can (2014, s.1) “eğitim sürecinde ölçme ve değerlendirme etkinlikleriyle yapılacak gözlemler sayesinde öğrenci davranışlarının hangi düzeyde olduğunun, ne tür yetersizliklerin bulunduğunun hatta istenmeyen davranışların olup olmadığının belirlenebileceği"ni belirtmiştir. Eğitimde ölçme ve değerlendirme sayesinde uygulanan etkinliklerin ne kadar etkili olup olmadığı ortaya konulmaktadır. Bu bakımdan eğitimde ölçme ve değerlendirme oldukça önem arz eden bir konu olarak görülmektedir.

Newfields (2006), tarafından ölçme değerlendirmenin önemi şu şekilde ifade edilmiştir: "Ölçme değerlendirme dünyadaki bütün eğitim sistemlerinin ortak parçasıdır, ölçme değerlendirme sayesinde eğitim programlarının nasıl işlediği anlaşılır ve ölçme değerlendirme öğretmenlere kendi performansını görme imkânı sağlar". Mertler ve Campbell (2005) "ölçme ve değerlendirme uygulamaları ne kadar uygun ve verimli bir şekilde kullanılırsa öğrencinin öğrenme performansının da o ölçüde artacağını" belirtmişlerdir. Baykul (1986) ölçme ve değerlendirmenin başlıca amaçlarını; öğrencilerin başarı düzeyini belirlemek, programın hedef ve davranışlarını irdelemek, öğretim sürecinin etkinliğini değerlendirmek ve öğrenciyi uygun programa yönlendirmek olarak ifade etmiştir. Ölçme ve değerlendirmenin öğretim sürecinde bazı önemli işlevleri bulunmaktadır. Nitekim Tezci (2016), öğretim sürecinde bu denli etkili olan ölçme değerlendirmenin işlevlerini şu şekilde sıralamaktadır:

1. Öğrenci hakkında verilecek kararlar ve bunlara ilişkin kanıtlar toplamak için kullanılabilir.

2. Öğretmen, öğrenme süreci sonunda öğrencinin gelişim durumunu değerlendirerek elde edeceği veriler ile öz değerlendirme yapabilir.

3. Programın değerlendirilmesi yapılabilir. 
4. Öğrenciyi yüksek not almaya ittiği ya da öğrencinin aldığ1 yüksek notla başarı duygusu hissettirebildiği için öğrenciyi motive edebilir.

5. Öğrenci ile yakından ilgisi olanlara (aile, okul yönetimi, öğretmenler vb.) öğrenci hakkında bilgi sağlar.

6. Eğitim sisteminin denetlenmesini sağlar.

7. Öğrenme öğretme sürecinin durumuna ilişkin verilecek kararlarda etkilidir. Öğrenme sürecinin gidişatı, öğrenmenin eksik ya da hatalı olduğu durumlar ölçme değerlendirme ile toplanan bilgiler sayesinde anlaşılır.

Eğitim ortamında etkili bir şekilde ölçme ve değerlendirme yapılabilmesinde öğretmenler baş aktörlerdir. Öğretmenlerin, kendilerini ölçme ve değerlendirme açısından yeterli olarak görmeleri hem eğitimi hem de öğrencilerin geleceğini olumlu yönde etkileyebilir. Öğretmen ölçme ve değerlendirme aracılığıyla öğrenciyi tanır, öğrenciye öğretim programındaki kazanımları kazanıp kazanmadığı, bilgi, beceri ve tutumlara sahip olup olmadığı ile ilgili dönütler verir (Tekin, 2019). Milli Eğitim Bakanlığı (MEB, 2017) “Öğretmenlik Mesleği Genel Yeterlikleri”nde öğretmenlerin sahip olması gereken mesleki becerilerinden birisinin de ölçme-değerlendirme olduğunu belirtmiştir. Bu bakımdan öğretmenlerin ölçme ve değerlendirme ile ilgili bilgilerinin olması ve ölçme-değerlendirmeye yönelik tutumlarının olumlu yönde olması son derece önemlidir.

Tutum, bireyin insan, nesne, olay ve olgularla ilgili, duygu ve davranışlarını düzenli bir biçimde oluşturan eğilim, tavırdır (Bakırcıoğlu, 2016, s. 1547). Diğer bir deyişle tutum "bireyi belli insanlar, nesneler ve durumlar karşısında belirli davranışı göstermeye yönelten öğrenilmiş bir eğilim" olarak tanımlanabilir (Demirel, 2003). Bireylerin tutumlarının bilinmesi, bireylerin karşılaştıkları uyaranlara nasıl tepki verecekleri noktasında tahminlerde bulunulmasını sağlar (Çalışkan ve Yazıcı, 2013). Bu bakımdan öğretmenlerin ölçme ve değerlendirmeye yönelik tutumlarının olumlu olması, onların ölçme ve değerlendirme araçlarını öğretme-öğrenme ortamında etkili bir şekilde kullanabileceklerine işaret edebilir.

Öğretmenlerin, öğretme ortamında etkili bir şekilde ölçme ve değerlendirme araçlarını kullanabilmeleri için hizmet öncesi eğitim dönemlerinde ölçme ve değerlendirmeye yönelik olumlu tutum geliştirmeleri gerekmektedir. Bu bakımdan lisans dönemlerinde, öğretmen adaylarının ölçme ve değerlendirmeye yönelik tutumlarının belirlenmesinin gerekliliği araştır- 
maya değer bir konu olarak düşünülmüştür. Bu düşüncenin neticesinde bu çalışmanın yapılmasına karar verilmiştir. Türkiye'deki alan yazın incelendiğinde öğretmen adaylarının ölçme ve değerlendirmeye yönelik tutumlarını inceleyen herhangi bir araştırmaya rastlanılmayışı da bu düşünceyi destekler niteliktedir. Bu durum alan yazında önemli bir boşluk olarak görülmektedir. Zira yukarıda da belirtildiği üzere öğretmen adaylarının ölçme ve değerlendirmeye yönelik tutumları, göreve başladıklarında ölçme ve değerlendirme araçlarını etkili bir şekilde kullanıp kullanamayacakları konusunda ipuçları verecektir. Bu bakımdan yapılan bu araştırmanın alan yazına katkı sağlayacağı söylenebilir. Özellikle Türkiye'de ölçme ve değerlendirmede tamamlayıcı ölçme-değerlendirme araçlarının kullanılamayışı, nitelikli ölçme ve değerlendirme yapılamayışı gibi sorunlar düşünüldügünde, öğretmen adaylarının ölçme ve değerlendirmeye yönelik tutumlarının belirlenmesi ve öğretmen yetiştirme kurumlarında ölçme ve değerlendirmeye yönelik çalışmaların yapılması, yaşanan sorunların en aza indirilmesine katkı sağlayacaktır.

$\mathrm{Bu}$ araştırma öğretmen adaylarının ölçme ve değerlendirmeye yönelik tutumlarının belirlenmesi ve ölçme ve değerlendirmeye yönelik tutumlarının cinsiyet, öğrenim görülen sınıf ve bölüm, üniversiteye giriş puan türü, akademik başarı ve ölçme-değerlendirme dersini yeterli bulma durumu değişkenleri ile ilişkisinin ortaya çıkarması ve elde edilen verilerin analizi, yani bulgular doğrultusunda öğretmen yetiştirme programlarını iyileştirici, düzenleyici ve yenileyici önlemler alınabilmesi açısından önemlidir. Yapılan bu araştırmanın bu bakımdan da alan yazına katkı sağlayacağı ve başta öğretmen adayları olmak üzere, öğretim üyelerine, öğretmen yetiştirme programlarına ve ilgili diğer kurumlara bir dönüt niteliği taşıyacağı düşünülmektedir. $\mathrm{Bu}$ bağlamda bu çalısmada öğretmen adaylarının ölçmedeğerlendirmeye yönelik tutumlarını çeşitli değişkenler açısından incelemek amaçlanmıştır. Bu amaç doğrultusunda da aşağıdaki sorulara yanıt aranmıştır:

1. Öğretmen adaylarının ölçme-değerlendirmeye yönelik tutum düzeyleri nedir?

2. Öğretmen adaylarının ölçme-değerlendirmeye yönelik tutumları arasinda;

a. cinsiyet değişkeni, 
b. öğrenim görülen sinıf düzeyi,

c. öğrenim görülen bölüm,

d. üniversiteye giriş puan türü,

e. akademik başarı,

f. ölçme-değerlendirme dersini yeterli bulup bulmama değişkenleri açısından anlamlı farklılık var mıdır?

\section{Yöntem}

\section{Araştırmanın Modeli}

Araştırmada, kesitsel tarama modeli kullanılmıştır. Fraenkel, Wallen ve Hyun (2014) tarafından bu modelde veri toplama sürecinin kısa sürdüğü ve verilerin bir defada toplandığı ifade edilmiştir. Özdemir (2014) ise bu tarama modelinde incelenen olgunun özelliklerinin var olduğu şekliyle betimlendiğini belirtmiştir. Bu araştırmada da veriler kısa bir sürede ve bir defada toplandığından bu model tercih edilmiştir.

\section{Çalışma Grubu}

Araştırmanın çalışma grubunu bir devlet üniversitesinin eğitim fakültesinde öğrenim görmekte olan 241 öğretmen adayı oluşturmaktadır. Araştırmanın çalışma grubu ise ölçüt örnekleme yöntemine göre belirlenmiştir. Bu örnekleme yönteminin amacı, araştırmacı tarafından oluşturulan veya daha önceden oluşturulmuş ölçüt ya da ölçütleri karşılayan örneklem grubuyla çalışmaktır (Yıldırım ve Şimşek, 2018). Bu araştırmada da, 3 ve 4. sınıflarda öğrenim görme ölçütü belirlenmiştir. Bunun temel nedeni ise, bu sınıflarda öğrenim gören öğretmen adaylarının ölçme-değerlendirme dersini almış olmaları, bu nedenle de araştırma neticesinde daha sağlıklı sonuçların elde edileceği düşüncesidir. Çalışma grubunun özellikleri Tablo 1'de yer almaktadır.

Tablo 1. Çalışma grubunun özellikleri

\begin{tabular}{lll}
\hline Cinsiyet & f & \% \\
\hline Kadın & 164 & 68 \\
Erkek & 77 & 32 \\
\hline Sınıf & & \\
\hline 3. sinff & 124 & 52 \\
4. sinuf & 117 & 48 \\
\hline Üniversiteye giriş puan türü & & \\
\hline Sözel & 38 & 16
\end{tabular}




\begin{tabular}{lll} 
Sayısal & 83 & 34 \\
Eşit Ă̆ırlık & 65 & 27 \\
Sayısal & 55 & 23 \\
\hline Bölüm & & \\
\hline Sınıf öğretmenliği & 63 & 26 \\
Fen bilgisi öğretmenliği & 56 & 23 \\
İngilizce öğretmenliği & 58 & 24 \\
Bilgisayar öğretmenliği & 26 & 11 \\
Sosyal bilgiler öğretmenliği & 38 & 16 \\
\hline Akademik başarı & & 3 \\
\hline $1.00-2.00$ arası & 7 & 64 \\
$2.01-3.00$ arası & 155 & 33 \\
$3.01-4.00$ arası & 79 & 62 \\
\hline Ölçme-değerlendirme dersini yeterli bulma & & 32 \\
\hline Yeterli & 150 & 6 \\
Kısmen yeterli & 76 & $\mathbf{1 0 0}$ \\
Yeterli değil & 15 & \\
\hline Toplam & $\mathbf{2 4 1}$ & \\
\hline
\end{tabular}

Tablo 1'de çalışma grubunda kadın öğretmen adaylarının fazla olduğu (\%68), öğretmen adaylarının çoğunun üçüncü sınıfta (\%52) ve sinıf öğretmenliğinde öğrenim gördükleri (\%26), çoğunluğunun üniversiteye giriş puan türünün sayısal olduğu (\%34), akademik başarılarının 2.01-3.00 arası olduğu (\%64) ve ölçme değerlendirme dersini yeterli buldukları (\%62) görülmektedir.

\section{Veri Toplama Araçlar}

Araştırmada iki tür veri toplama aracı kullanılmıştır. Bunlar;

Kişisel bilgiler formu: Araştırmada kişisel bilgiler formu kullanılmıştır. Bu form alanında uzman kişilerin görüşü ve alan yazındaki çalışmalar dikkate alınarak oluşturulmuştur. Kişisel bilgiler formunda katılımclların cinsiyetlerini, sınıf düzeylerini, öğrenim gördükleri bölümü, üniversiteye giriş puan türlerini, akademik başarılarını ve ölçme-değerlendirme dersini yeterli bulup bulmama durumların belirmeye yönelik sorular bulunmaktadır.

Ölçme ve değerlendirme tutum ölçeği: Araştırma kapsamında Arastaman, Yıldırım ve Daşçı (2015) tarafından geliştirilen “Ölçme ve Değerlendirmeye Yönelik Tutum Ölçeği" kullanılmıştır. Ölçek, Aksaray ilindeki 301 branş öğretmenine uygulanarak analizi yapılmıştır. Ölçek geliştirilirken öncelikle açımlayıcı faktör analizi (AFA) yapılmıştır. AFA sonucunda, ölçeğin 4 alt boyuttan ve 21 maddeden oluştuğu tespit edilmiştir. AFA neticesinde ölçe- 
ğin faktörleri; "Ölçme aracı hazırlama”, "Uygulama”, "Temel kavramları bilme" ve "Alternatif ölçme araçları" olarak isimlendirilmiştir.

Ölçeğin Ölçme aracı hazırlama faktörüne "Ölçme aracı geliştirirken zorlanmam.", Uygulama faktörüne "Ölçme aracının nasıl kullanılması gerektiğini bilirim.", Temel kavramları bilme faktörüne "Ölçme ve değerlendirme kavramlarını bilirim." ve Alternatif ölçme araçları faktörüne "Alternatif ölçme araçları hakkında bilgi sahibiyim." maddeleri örnek verilebilir (Arastaman, Yıldırım ve Daşçı, 2015). Ölçeğin tüm boyutları toplam varyansın \%67'sini açılamaktadır. Ölçeğe ait madde faktör yükleri .52 ile .81 arasında değişmektedir. Ölçek geliştirilirken Cronbach Alpha katsayıları da incelenerek ölçeğin güvenirlik hesaplamaları yapılmıştır. Yapılan analizler neticesinde ölçeğin birinci faktörüne ait Caronbach Alpha katsayısı .90, ikinci faktörün .89 , üçüncü faktörün .83 , dördün faktörün .82 ve tamamı için .94 bulunmuştur. Ölçeğin tüm boyutlarına ait madde test korelasyonunun .44 ile .73 arasında değiştiği tespit edilmiştir. Yapılan doğrulayıcı faktör analizi neticesinde de ölçeğin uyum indeksleri istenilen düzeyde çıkmıştır. Ölçek yedili likert tipinde geliştirilmiştir (Arastaman, Yıldırım ve Daşçı, 2015).

Arastman, Yıldırım ve Daşçı (2015) tarafından geliştirilen “Ölçme ve Değerlendirmeye Yönelik Tutum Ölçeği" öğretmenler üzerinde yürütülmüştür. Bu araştırmada da bu ölçek ile öğretmen adaylarının görüşleri alınmıştır. Yapılan bu araştırmada ölçek kullanılmadan önce farklı üniversitelerde, eğitim bilimleri bölümünde görev yapan dört öğretim üyesinin görüşüne başvurulmuştur. Öğretim üyelerine ölçek gönderilmiş ve öğretmen adayları üzerinde uygulanıp uygulanamayacağı ile ilgili görüşleri alınmıştır. Öğretim üyeleri ölçeğin öğretmen adaylarına uygulanabileceğine, ancak beşli likert şeklinde düzenlenmesinin daha iyi olacağına yönelik görüş belirtmişlerdir. Bunun üzerine araştırmacı, araştırma kapsamında analizlerini gerçekleştirmeden önce toplanan verilerle AFA yapmıştır. AFA geçmeden önce $\mathrm{KMO}$ ve Bartlett's testi incelenmiş ve KMO değerinin .91 ve Bartlett's küresellik testinin anlamlı çıktığı tespit edilmiştir. Ölçeğin aslında olduğu gibi dört faktör altında toplandığı görülmüştür. Ölçeğin toplam varyansı 61.23'tür. Ölçeğin faktör yüklerinin .49 ile .81 arasında değiştiği tespit edilmiştir. Ölçeğin Cronbach Alpha güvenirlik katsayı incelenmiştir. Yapılan analizler sonucunda ölçeğin güvenirlik katsayısı .93 bulunmuştur. Bu sonuç, ölçeğin oldukça güvenilir olduğunu göstermektedir (Fraenkel, Wallen ve Hyun, 2014). Tüm bu analizler neticesinde ölçeğin öğretmen adaylarına 
uygulanabileceği görülmüştür. Şekil 1'de yer alan yamaç birikinti grafiği incelendiğinde de, ölçeğin 4 faktör altında toplandığı görülmektedir.

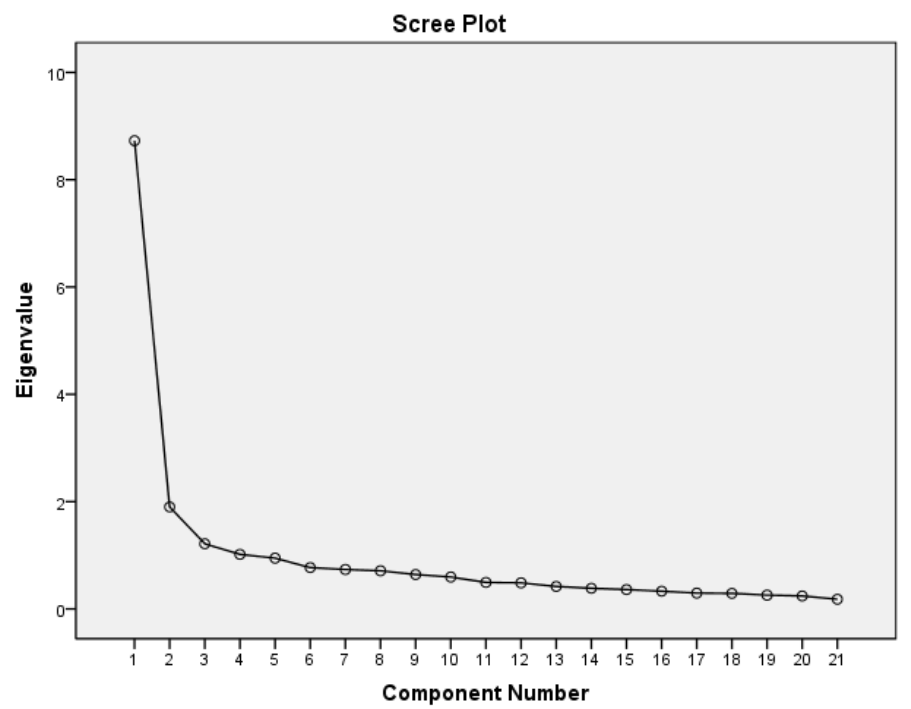

Şekil 1. Yamaç birikinti grafiği

\section{Verilerin Toplanması}

Araştırmanın verileri 2019-2020 eğitim-öğretim yılının bahar döneminde 213/03/2020 tarihleri arasında toplanmıştır. Veriler toplanırken gerekli izinler alınmış ve etik kurul kararı (Sayı:874329561/050.991) çıkarılmıştır. Araştırmanın verileri toplanırken katılımcıların rızalarının alınması sağlanılmıştır. Katılımcılara araştırmaya gönüllü katılım beyanı dağıtılarak veri toplama aracı uygulanmıştır. Veriler, öğretmen adaylarının öğrenimlerini olumsuz bir şekilde etkilemeyecek zaman aralıklarında toplanmıştır. Öğretmen adayları kişisel bilgiler formunu ve ölçek maddelerini yaklaşık 15 dakikada doldurmuşlardır. Araştırmanın tüm aşamalarında etik ilkelere riayet edilmiştir.

\section{Verilerin Analizi}

Araştırmada veriler analiz edilmeden önce uç değerlerin olup olmadığına bakılmış ve $Z$ puanlarına bakılarak iki ölçek uç değer olarak tespit edilmiştir. Uç değerlere sahip bu iki ölçek araştırmadan çlkartılmıştır. Parametrik 
analizlerin yapılabilmesi için öncelikle tek değişkenli normallik varsayımı incelenmiştir. Bunun için Kolmogorov-Smirnov testinin sonuçlarına bakılmıştır. Yapılan analiz neticesinde verilerin normal dağılım sergilemediği tespit edilmiştir (K-S=.099, p<.05). Ho (2006) ve Seçer (2015) bu durumda çarpıklık ve basıklık katsayılarının incelenmesini önermektedir. Can (2019) çarpıklık ve basıklık değerlerinin +1.96 ile -1.96 arasında olması gerektiğini belirtmiştir. Yapılan analiz neticesinde ölçeğin çarpıklık katsayısı -.723 ve standart hatası .157, basıklık katsayısı .374 ve standart hatası .314 bulunmuştur. Bu sonuçlara dayalı olarak, parametrik analizlerin yapılabilme koşullarından biri olan tek değişkenli normallik varsayımının karşılandığı söylenebilir.

Verilerin analizinde bağımsız örneklemler t-testi, betimsel istatistik ve tek yönlü varyans analizi (ANOVA) kullanılmıştır. Bağımsız örneklemler ttestinin uygulanabilmesi için iki grubun rastlantısal ve puanlarının birbirinden bağımsız olması, tek değişkenli normalliğin sağlanması ve puanların temsil ettiği evrenlerin varyanslarının homojen olması varsayımlarının karşlanması gerekmektedir (Green ve Salkind, 2014). Pallant (2005) varyansların homojenliği sağlanmadığı durumda $t$ testinde equal variances not assumed sütunundaki değerlerin incelenmesi gerektiğini önermektedir. Bu araştırmada bu varsayım sağlanmadığında equal variances not assumed sütunundaki değerler incelenip ilgili tablolara yazılmıştır. ANOVA yapabilmek için de bağımlı değişkenin her grup için ayrı ayrı normal dağılım göstermesi ve grupların bağımlı değişken verisine ilişkin varyansları birbirine benzer olması varsayımlarının karşılanması gerekmektedir (İyilikci, 2020). Araştırma kapsamında yapılan analizlerin etki büyüklükleri de hesaplanmış ve ilgili tablolarda sunulmuştur. Green ve Salkind (2014) bağımsız örneklemler $\mathrm{t}$ testinde $\mathrm{d}$ değerini .02 ve altını küçük .05 ile .08 arasını orta ve .08 ve üstünü yüksek etki büyüklüğü olarak ifade etmiştir. ANOVA'da ise eta kare $\left(\eta^{2}\right)$ değerinin alacağı .01 değerini küçük, .06 değerini orta ve .14 değeri geniş etki büyüklüğü olarak yorumlanır (Green ve Salkind, 2014). ANOVA sonucunda anlamlı farklılığın hangi grupların lehine olup olmadığın belirlemek için LSD ve Scheffe testi uygulanmıştır. Pallant (2005) ANOVA'da gruplar arasındaki farkın belirlenmesinde daha liberal olan LSD testinin kullanılması gerektiğini önermektedir. Grupların sayılarının birbirine yakın olmaması durumunda ise Scheffe testinin uygulanması gerektiğini önermektedir. Bu 
nedenle bu araştırmada ANOVA yapılan değişkenlerde hem LSD hem de Scheffe testi uygulanmiştır.

\section{Bulgular}

Araştırmanın bu bölümünde elde edilen bulgular alt problemler dikkate alınarak sunulmuştur. Araştırmanın birinci alt problemine dayalı olarak öğretmen adaylarının ölçme ve değerlendirmeye yönelik tutumları incelenmiş ve elde edilen sonuçlar Tablo 2'de sunulmuştur.

Tablo 2. Öğretmen adaylarının ölçme ve değerlendirmeye yönelik tutumlarn

\begin{tabular}{lllllll}
\hline \multirow{2}{*}{ Ölçek } & $\mathbf{N}$ & $\bar{X}$ & SS & Min & Max & Düzey \\
\cline { 2 - 7 } & 239 & 3.73 & .56 & 2.10 & 4.86 & Yüksek \\
\hline
\end{tabular}

Tablo 2 incelendiğinde, öğretmen adaylarının ölçme ve değerlendirmeye yönelik tutumlarının ( $\overline{\mathrm{X}}=3.73$ ) "yüksek" düzeyde olduğu tespit edilmiştir.

Araştırmanın ikinci alt problemine dayalı olarak öğretmen adaylarının ölçme ve değerlendirmeye yönelik tutumları arasında cinsiyet değişkeni açısından anlamlı farklılık olup olmadığı incelenmiş ve elde edilen bulgular Tablo 3'te sunulmuştur.

Tablo 3. Cinsiyet değişkenine ilişkin t-Testi sonuçları

\begin{tabular}{|c|c|c|c|c|c|c|c|}
\hline \multirow{3}{*}{$\begin{array}{l}\text { Ölçme ve Değerlendirmeye } \\
\text { Yönelik Tutum }\end{array}$} & Cinsiyet & $\mathbf{n}$ & $\bar{X}$ & SS & $t$ & p & $d$ \\
\hline & Kadın & 163 & 3.80 & .53 & \multirow{2}{*}{2.87} & \multirow{2}{*}{$.00^{*}$} & \multirow{2}{*}{.39} \\
\hline & Erkek & 76 & 3.58 & .60 & & & \\
\hline
\end{tabular}

\begin{tabular}{ll}
\hline Levene: 2.707 & $\mathrm{p}: .10$ \\
\hline${ }^{*} \mathrm{p}<.05$ &
\end{tabular}

Tablo 3 incelendiğinde, öğretmen adaylarının ölçme ve değerlendirmeye yönelik tutumları arasında cinsiyet değişkeni açısından anlamlı farklılık elde edilmiştir ( $\mathrm{t}=2.87, \mathrm{p}<.05)$. Ortalamalar incelendiğinde kadın öğretmen adaylarının ( $\overline{\mathrm{X}}=3.80$ ) lehine anlamlı farklılık olduğu görülmektedir. Tabloda etki büyüklüğünün yüksek düzeyde olduğu görülmektedir.

Araştırmanın üçüncü alt problemine dayalı olarak, öğretmen adaylarının ölçme ve değerlendirmeye yönelik tutumları arasında öğrenim görülen sınıf düzeyi değişkeni açısından anlamlı derecede farklılık olup olmadığını belirlemek için $\mathrm{t}$ testi yapılmış ve sonuçlar Tablo 4'te verilmiştir. 
Tablo 4. Öğrenim görülen sınıf değişkenine ilişkin t-Testi sonuçlan

\begin{tabular}{|c|c|c|c|c|c|c|c|}
\hline Ölçme ve & Sinif & $\mathbf{n}$ & $\bar{X}$ & SS & $\mathbf{t}$ & p & $d$ \\
\hline Değerlendirmeye & 3. sinif & 122 & 3.67 & .60 & \multirow{2}{*}{-1.64} & \multirow{2}{*}{.10} & \multirow{2}{*}{.20} \\
\hline Yönelik Tutum & 4. sinif & 117 & 3.79 & .51 & & & \\
\hline
\end{tabular}

Tablo 4 incelendiğinde, öğretmen adaylarının ölçme ve değerlendirmeye yönelik tutumları arasında öğrenim görülen sınıf değişkeni açısından anlamlı farklılık elde edilmemiştir ( $\mathrm{t}=-1.64, \mathrm{p}>.05)$. Tablo 4 incelendiğinde üçüncü ( $\bar{X}=3.67$ ) ve dördüncü ( $\bar{X}=3.79$ ) sinıflarda öğrenim gören öğretmen adaylarının ortalamalarının birbirine yakın olduğu görülmektedir.

Araştırmanın dördüncü alt problemine dayalı olarak, öğretmen adaylarının ölçme ve değerlendirmeye yönelik tutumları arasında öğrenim görülen bölüm değişkeni açısından anlamlı derecede farklılık olup olmadığını belirlemek için ANOVA yapılmış ve sonuçlar Tablo 5'te verilmiştir.

Tablo 5. Öğrenim görülen bölïm değişkenine ilişkin ANOVA sonuçlar

\begin{tabular}{|c|c|c|c|c|c|c|c|c|c|c|}
\hline Bölüm & $\mathbf{n}$ & $\bar{X}$ & SS & Gruplar & $\begin{array}{l}\text { Kareler } \\
\text { Toplamı }\end{array}$ & sd & $\begin{array}{l}\text { Kareler } \\
\text { Ortalaması }\end{array}$ & $\mathbf{F}$ & $\mathrm{p}$ & $\eta^{2}$ \\
\hline A & 63 & 3.83 & .43 & \multirow{2}{*}{ Gruplar arasi } & \multirow{2}{*}{9.13} & \multirow{5}{*}{$4-238$} & & \multirow{5}{*}{7.98} & \multirow{5}{*}{$.00^{*}$} & \multirow{6}{*}{.12} \\
\hline $\mathrm{B}$ & 55 & 3.99 & .55 & & & & 2.283 & & & \\
\hline $\mathrm{C}$ & 58 & 3.45 & .57 & Gruplar içi & 66.885 & & & & & \\
\hline D & 26 & 3.63 & .59 & \multirow{2}{*}{ Toplam } & \multirow{2}{*}{76.017} & & .286 & & & \\
\hline E & 37 & 3.66 & .55 & & & & & & & \\
\hline \multicolumn{2}{|c|}{ Levene: 2.465} & \multicolumn{2}{|c|}{ p: .06} & & \multicolumn{3}{|c|}{ LSD: $A>C ; B>C ; B>D ; B>E$} & & & \\
\hline
\end{tabular}

A: Sinuf Öğrt.; B: Fen Bilgisi Öğrt. C: İngilizce Öğrt; D: Bilgisayar Öğrt; E: Sosyal Bilgiler Öğrt

Tablo 5 incelendiğinde, öğretmen adaylarının ölçme ve değerlendirmeye yönelik tutumları arasında öğrenim görülen bölüm değişkeni açısından anlamlı farklılık elde edilmiştir ( $F=7.98, p<.05)$. Yapılan LSD testi sonucunda sınıf ve İngilizce öğretmenliğinde öğrenim gören öğretmen adayları arasında, sınıf öğretmenliğinde öğrenim gören öğretmen adaylarının lehine; fen bilgisi, İngilizce, bilgisayar ve sosyal bilgiler öğretmenliğinde öğrenim gören öğretmen adayları arasında fen bilgisi öğretmenliğinde öğrenim gören öğretmen adaylarının lehine anlamlı farklılık elde edilmiştir. Tabloda etki büyüklüğünün orta düzeyde olduğu görülmektedir.

Araştırmanın beşinci alt problemine dayalı olarak, öğretmen adaylarının ölçme ve değerlendirmeye yönelik tutumları arasında üniversiteye giriş 
puan türü değişkeni açısından anlamlı derecede farklılık olup olmadığını belirlemek için ANOVA yapılmış ve sonuçlar Tablo 6' da verilmiştir.

Tablo 6. Üniversiteye giriş puan türü değişkenine ilişkin ANOVA sonuçları

\begin{tabular}{|c|c|c|c|c|c|c|c|c|c|c|}
\hline $\begin{array}{l}\text { Puan } \\
\text { Türü }\end{array}$ & $\mathbf{n}$ & $\bar{X}$ & SS & Gruplar & $\begin{array}{l}\text { Kareler } \\
\text { Toplamı }\end{array}$ & sd & $\begin{array}{l}\text { Kareler } \\
\text { Ortalamas1 } \\
\end{array}$ & $\mathbf{F}$ & $\mathbf{p}$ & $\eta^{2}$ \\
\hline A & 37 & 3.65 & .56 & Gruplar & & \multirow{4}{*}{ 3-235 } & & \multirow{4}{*}{5.79} & \multirow{4}{*}{$.00^{*}$} & \multirow{4}{*}{.06} \\
\hline B & 82 & 3.87 & .57 & arasi & 5.238 & & 1.746 & & & \\
\hline C & 65 & 3.80 & .48 & $\begin{array}{l}\text { Gruplar } \\
\text { içi }\end{array}$ & 70.780 & & \multirow[t]{2}{*}{.301} & & & \\
\hline $\mathrm{D}$ & 55 & 3.73 & .56 & Toplam & 76.017 & & & & & \\
\hline \multicolumn{2}{|c|}{ Levene: .440 } & \multicolumn{2}{|c|}{ p: .72} & & \multicolumn{3}{|c|}{ LSD: $\mathrm{B}>\mathrm{A} ; \mathrm{B}>\mathrm{D} ; \mathrm{C}>\mathrm{D}$} & & & \\
\hline
\end{tabular}

A:Sözel; B: Sayısal; C: Eşit Ağırlık; D: Yabancı dil

Tablo 6 incelendiğinde, öğretmen adaylarının ölçme ve değerlendirmeye yönelik tutumları arasında üniversiteye giriş puan türü değişkeni açısından anlamlı farklılık elde edilmiştir ( $F=5.79, p<.05)$. Yapılan LSD testi sonucunda eşit ağırlık ve yabancı dil puan türü ile üniversiteye giriş yapan öğretmen adayları arasında, eşit ağırlık puan türünden giren öğretmen adaylarının lehine; sayısal, sözel ve yabancı dil puan türünden üniversiteye giren öğretmen adayları arasında sayısal puan türünden giren öğretmen adaylarının lehine anlamlı farklılık elde edilmiştir. Tabloda etki büyüklüğünün orta düzeyde olduğu görülmektedir.

Araştırmanın altıncı alt problemine dayalı olarak, öğretmen adaylarının ölçme ve değerlendirmeye yönelik tutumları arasında akademik başarı değişkeni açısından anlamlı derecede farklılık olup olmadığını belirlemek için ANOVA yapılmış ve sonuçlar Tablo 7' de verilmiştir.

Tablo 7. Akademik başarı değişkenine ilişkin ANOVA sonuçlan

\begin{tabular}{|c|c|c|c|c|c|c|c|c|c|c|}
\hline Başarı & $\mathbf{n}$ & $\bar{X}$ & SS & Gruplar & $\begin{array}{l}\text { Kareler } \\
\text { Toplamı } \\
\end{array}$ & sd & $\begin{array}{l}\text { Kareler } \\
\text { Ortalaması }\end{array}$ & F & $\mathrm{p}$ & $\eta^{2}$ \\
\hline A & 7 & 3.31 & .60 & \multirow{2}{*}{ Gruplar arası } & \multirow{2}{*}{1.754} & \multirow{4}{*}{$\begin{array}{l}2- \\
236\end{array}$} & & \multirow{4}{*}{2.78} & \multirow{4}{*}{.06} & \multirow{4}{*}{.02} \\
\hline B & 154 & 3.71 & .57 & & & & .877 & & & \\
\hline \multirow{2}{*}{ C } & \multirow{2}{*}{78} & \multirow{2}{*}{3.81} & \multirow{2}{*}{.53} & Gruplar içi & 74.264 & & \multirow{2}{*}{.315} & & & \\
\hline & & & & Toplam & 76.017 & & & & & \\
\hline Leven & 043 & & & & & & & & & \\
\hline
\end{tabular}

A: $1.00-2.00$ arası; B: $2.01-3.00$ aras1; C: $3.01-4.00$ aras1

Tablo 7 incelendiğinde, öğretmen adaylarının ölçme ve değerlendirmeye yönelik tutumları arasında akademik başarı değişkeni açısından anlamlı farklılık saptanmamıştır ( $F=2.78, \mathrm{p}>.05)$. 
Araştırmanın yedinci alt problemine dayalı olarak, öğretmen adaylarının ölçme ve değerlendirmeye yönelik tutumları arasında ölçme-değerlendirme dersini yeterli bulma değişkeni açısından anlamlı derecede farklılık olup olmadığını belirlemek için ANOVA yapılmış ve sonuçlar Tablo 8'de verilmiştir.

Tablo 8. Ölçme-değerlendirme dersini yeterli bulma değişkenine ilişkin ANOVA sonuçla-

\begin{tabular}{|c|c|c|c|c|c|c|c|c|c|c|}
\hline $\begin{array}{l}\text { Puan } \\
\text { Türü }\end{array}$ & $\mathbf{n}$ & $\bar{X}$ & SS & Gruplar & $\begin{array}{l}\text { Kareler } \\
\text { Toplamı }\end{array}$ & sd & $\begin{array}{l}\text { Kareler } \\
\text { Ortalaması }\end{array}$ & F & p & $\eta^{2}$ \\
\hline A & 149 & 3.93 & .47 & Gruplar & & \multirow{4}{*}{$2-236$} & & \multirow{4}{*}{35.24} & \multirow{4}{*}{$.00^{*}$} & \multirow{4}{*}{.23} \\
\hline B & 76 & 3.42 & .52 & arasi & 17.484 & & 8.742 & & & \\
\hline \multirow{2}{*}{ C } & \multirow{2}{*}{14} & \multirow{2}{*}{3.19} & \multirow{2}{*}{.62} & Gruplariçi & 58.534 & & \multirow{2}{*}{.248} & & & \\
\hline & & & & Toplam & 76.017 & & & & & \\
\hline Leven & & p: .14 & & Sch & $f e: \quad \mathrm{A}>\mathrm{B} ; \mathrm{A}$ & & & & & \\
\hline
\end{tabular}

A: Yeterli; B: Kısmen yeterli; C: Yeterli değil

Tablo 8 incelendiğinde, öğretmen adaylarının ölçme ve değerlendirmeye yönelik tutumları arasında ölçme-değerlendirme dersini yeterli bulma değişkeni açısından anlamlı farklılık elde edilmiştir ( $\mathrm{F}=35.24, \mathrm{p}<.05)$. Yapılan Scheffe testi sonucunda ölçme-değerlendirme dersini yeterli, kısmen yeterli ve yetersiz bulanlar arasında, yeterli bulan öğretmen adaylarının lehine anlamlı farklılık elde edilmiştir. Tabloda etki büyüklüğünün yüksek düzeyde olduğu görülmektedir.

\section{Tartışma, Sonuç ve Öneriler}

$\mathrm{Bu}$ araştırmada, öğretmen adaylarının ölçme ve değerlendirmeye yönelik tutumları çeşitli değişkenler açısından incelenmiştir. Türkiye'de daha çok ölçme ve değerlendirme ile öğretmenler üzerinde çalışmalar yürütülmüştür. Bu durum araştırmanın sonuçlarının alan yazındaki sonuçlarla tartışılmasını sınırlandırmaktadır. Nitekim araştırma kapsamında incelenen öğrenim görülen bölüm ve sınıf düzeyi, üniversiteye giriş puan türü, akademik başarı ile ölçme-değerlendirme dersini yeterli bulma durumu değişkenleri ile ilgili olarak herhangi bir araştırma sonucuna ulaşılmamıştır. Bu nedenle, yapılan bu araştırma kapsamında bu değişkenlerle ilgili tartışma yürütülememiştir.

Araştırma sonunda, öğretmen adaylarının ölçme ve değerlendirmeye yönelik tutumlarının "yüksek" düzeyde olduğu tespit edilmiştir. Bu sonuç araştırmanın önemli bir sonucu olarak değerlendirilmektedir. Zira öğret- 
men adaylarının ölçme ve değerlendirmeye yönelik tutumları onların göreve başladıklarında nitelikli bir şekilde ölçme ve değerlendirme araçlarını uygulayacaklarını düşündürmektedir. Bunun neticesinde de Türkiye'de ölçme ve değerlendirmede yaşanan sorunlar en aza indirilebilir. Bu nedenle, araştırmanın bu sonucu gelecek açısından ümit vadetmektedir. Aslan (2019) tarafından yapılan araştırmada, öğretmen adaylarının tamamlayıcı ölçme değerlendirme ile ilgili bilgilerinin yeterli düzeyde olduğu sonucu elde edilmiştir. Karaman ve Şahin (2014) tarafından yapılan araştırmada, öğretmen adaylarının ölçme-değerlendirme okuryazarlık düzeyleri düşük bulunmuştur. Çalışkan ve Yazıcı (2013) tarafından yapılan araştırmada sosyal bilgiler öğretmenlerinin ölçme ve değerlendirmeye yönelik tutumlarının düşük düzeyde olduğu tespit edilmiştir.

Araştırmada ortaya çıkan diğer bir sonuç ise öğretmen adaylarının ölçme ve değerlendirmeye yönelik tutumları arasında cinsiyet değişkeni açısından kadın öğretmen adaylarının lehine anlamlı farklılık olmasıdır. Bu sonuca dayalı olarak, kadın öğretmen adaylarının ölçme ve değerlendirmeye daha olumlu tutum geliştirdikleri söylenebilir. Bu sonuç, kadın öğretmen adaylarının göreve başladıklarında ölçme ve değerlendirme araçlarını etkili bir şekilde kullanacakları şeklinde yorumlanabilir. Çalışkan ve Yazıcı (2013) tarafından yapılan araştırmada sosyal bilgiler öğretmenlerinin ölçme ve değerlendirmeye yönelik tutumları arasında cinsiyet değişkeni açısından anlamlı farklılık elde edilmemiştir. Şahin ve Karaman (2013) tarafından yapılan araştırmada öğretmen adaylarının ölçme ve değerlendirmeye yönelik inançları arasında cinsiyet değişkeni açısından kadın öğretmen adaylarının lehine anlamlı farklılık elde edilmiştir. Bu sonuç ile yapılan bu araştırmanın sonucu örtüşmektedir. Kılıç (2014) tarafından yapılan araştırmada da öğretmenlerin otantik ölçme ve değerlendirmeye yönelik tutumlar arasında cinsiyet değişkeni açısından anlamlı farklılık elde edilmiştir.

Araştırmada öğretmen adaylarının ölçme ve değerlendirmeye yönelik tutumları arasında öğrenim gördükleri sınıf düzeyleri ile bölümleri açısından anlamlı farklılık olup olmadığ 1 incelenmiştir. Araştırma neticesinde, öğretmen adaylarının ölçme ve değerlendirmeye yönelik tutumları arasında öğrenim görülen sınıf değişkeni açısından anlamlı farklılık elde edilmezken, öğrenim görülen bölüm açısından sınıf ve fen bilgisi öğretmenliği bölümlerinde öğrenim gören öğretmen adaylarının lehine anlamlı farklılık elde edilmiştir. Bu sonuçlara dayalı olarak, öğretmen adaylarının ölçme ve de- 
ğerlendirmeye yönelik tutumları arasında öğrenim görülen sınıf düzeyinin etkili olmadığı, ancak bölümün etkili olduğu yorumu yapılabilir.

Araştırmada yapılan analizler neticesinde üçüncü ve dördüncü sınıflarda öğrenim gören öğretmen adaylarının ölçme ve değerlendirmeye yönelik tutumlarına ait ortalamaların birbirine yakın olduğu tespit edilmiştir. Bu sonuç gösteriyor ki, öğretmen adaylarının ölçme ve değerlendirmeye yönelik tutumları yüksek düzeyde ve birbirine benzerdir. Sinıf ve fen bilgisinde öğrenim gören öğretmen adaylarının ölçme değerlendirmeye yönelik tutumlarının anlamlı çıkmasının nedeni olarak bu programlarda sayısal derslerin olması gösterilebilir. Ayrıca bu programlarda yer alan ölçme ve değerlendirme dersine giren öğretim elamanlarının nitelikli bir şekilde bu dersi vermeleri de bu durumun ortaya çıkmasına neden olmuş olabilir.

Araştırma sonucunda öğretmen adaylarının ölçme ve değerlendirmeye yönelik tutumları arasında üniversiteye giriş puan türü değişkeni açısından eşit ağırlık ve sayısal puan türlerinden üniversiteye giren öğretmen adaylarının lehine anlamlı farklılık elde edilmiştir. Bu sonuç, üniversiteye giriş puan türünün öğretmen adaylarının ölçme ve değerlendirmeye yönelik tutumları üzerinde anlamlı fark yaratan bir değişken olduğunu ortaya koymaktadır. Araştırmanın bu sonucu beklenen bir durumdur. Zira eşit ağırlık ve sayısal puan türünden üniversiteye giren öğretmen adayları, öğrenim gördükleri liselerde sayısal ağırlıklı dersler almaktadırlar. Bu nedenle, bu puan türlerinden üniversiteye giriş yapan öğretmen adaylarının ölçme ve değerlendirmeye yönelik tutumlarının yüksek düzeyde olması ve anlam11 çıkması anlaşılır bir durumdur. Bu sonuç yukarıda belirtilen bölüm değişkenine göre anlamlı farklılı̆̆ın çıkmasını da destekler niteliktedir. Çünkü yukarıda da belirtildiği üzere sınıf ve fen bilgisi öğretmenliği programlarında sayısal dersler bulunmaktadır. Bu derslerin olması öğretmen adaylarının ölçme ve değerlendirmeye yönelik tutumlarını olumlu yönde etkilemiş olabilir. Ayrıca sınıf öğretmenliği programının eşit ağırlık puan türünden, fen bilgisi öğretmenliği programının sayısal puan türünden öğrenci alıyor olması bu farklılı̆̆ın ortaya çıkmasına neden olmuş olabilir.

Araştırma sonunda öğretmen adaylarının ölçme ve değerlendirmeye yönelik tutumları arasında akademik başarı değişkeni açısından anlamlı farklılık elde edilmemiştir. Bu sonuç oldukça ilgi çekici bir sonuçtur. Çünkü akademik başarısı yüksek olan bireylerin tutumlarının da yüksek olması beklenen bir durumdur. Araştırmada, öğretmen adaylarının ölçme ve de- 
ğerlendirmeye yönelik tutum ortalamaları incelendiğinde akademik başarısı yüksek olan öğretmen adaylarının daha çok olumlu tutuma sahip oldukları belirlenmiştir. Buna dayalı olarak akademik başarı açısından anlamlı farklılık çıkmasa da, öğretmen adaylarının akademik başarıları yükseldikçe ölçme ve değerlendirmeye yönelik tutumlarının olumlu yönde arttı̆̆ söylenebilir.

Araştırmada son olarak öğretmen adaylarının ölçme ve değerlendirmeye yönelik tutumları arasında ölçme ve değerlendirme dersini yeterli bulma değişkeni açısından anlamlı farklılık olup olmadığ incelenmiştir. Araştırma sonucunda, öğretmen adaylarının ölçme ve değerlendirmeye yönelik tutumları arasında ölçme-değerlendirme dersini yeterli bulma değişkeni açısından yeterli bulan öğretmen adaylarının lehine anlamlı farklılık elde edilmiştir. Bu sonuca dayalı olarak, ölçme-değerlendirme dersini yeterli bulma durumunun öğretmen adaylarının ölçme ve değerlendirmeye yönelik tutumları üzerinde anlamlı etki yarattı̆̆ ifade edilebilir. Bu sonuç da araştırmanın önemli bir sonucudur. Öğretmen yetiştirme programlarında yer alan ölçme ve değerlendirme dersinin nitelikli bir şekilde verilmesinin, öğretmen adaylarının ölçme ve değerlendirmeye yönelik tutumlarının olumlu yönde gelişmesine katkı sağladığını ortaya koymaktadır.

Araştırmanın sonuçlarına dayalı olarak şu önerilerde bulunulabilir:

1. Öğretmen adaylarının ve öğretmenlerin ölçme ve değerlendirmeye yönelik tutumları arasında karşılaştırmalı araştırmalar yapılabilir.

2. Araştırmada sınıf ve fen bilgisi öğretmenliğinde öğrenim gören öğretmen adaylarının lehine ölçme ve değerlendirme tutumları arasında anlamlı farklılık çıkmıştır. Diğer bölümlerde ölçme ve değerlendirmeye yönelik tutumların düşük çıkmasının nedenleri araştırılabilir.

3. Türkiye'nin farklı bölgelerindeki üniversitelerde öğrenim gören öğretmen adaylarının ölçme ve değerlendirmeye yönelik tutumlarını inceleyen araştırmalar yapılabilir.

4. Araştırmada öğretmen adaylarının ölçme değerlendirme dersini yeterli bulmalarının ölçme ve değerlendirmeye yönelik tutumlarını olumlu yönde anlamlı derece etkilediği sonucu elde edilmiştir. Öğretmen yetiştirme programlarında bu dersi veren öğretim elemanlarının öğretme ortamını etkili bir şekilde düzenleyerek bu dersi vermeleri, ölçme ve değerlendirmeye yönelik tutumun olumlu yönde gelişmesine katkı sağlayacaktır. 


\section{EXTENDED ABSTRACT}

\section{An Investigation Of Prospective Teachers Attitudes For Measurement Assessment In Terms Of Various Variables

\author{
* \\ Serkan Aslan \\ Süleyman Demirel Üniversitesi
}

Teachers are the main actors in effective measurement and evaluation in the educational environment. Teachers' seeing themselves as sufficient in terms of measurement and evaluation can positively affect both education and the future of students. The teacher recognizes the student through measurement and evaluation, and gives feedback on whether the student has acquired the achievements in the curriculum and whether he / she has knowledge, skills and attitudes (Tekin, 2019). The Ministry of National Education (MEB, 2017) stated that one of the professional skills teachers should have in the "General Competencies for Teaching Profession" is measurement and evaluation. In this respect, it is extremely important for teachers to have knowledge about measurement and evaluation and to have a positive attitude towards measurement-evaluation.

This study reveals the relationship between prospective teachers attitudes towards measurement and evaluation and their attitudes towards measurement and evaluation with the variables of gender, class and department of education, type of university entrance score, academic achievement and finding the measurement and evaluation course sufficient, and the analysis of the data obtained, In other words, it is important in terms of taking measures to improve, regulate and renew teacher training programs in line with the findings. It is thought that this study will contribute to the literature in this respect and will serve as a feedback for prospective teachers, faculty members, teacher training programs and other relevant institutions. In this context, this study aimed to examine the attitudes of prospective teachers towards measurement and evaluation in terms of various variables. For this purpose, answers to the following questions were sought: 
1. What are the prospective teachers attitude levels towards measurement and evaluation?

2. Among the prospective teachers attitudes towards measurement and evaluation;

a) gender variable,

b) grade level of education,

c) department of education,

d) university entrance score type,

e) academic success,

f) Is there a significant difference in terms of the variables of finding the assessment-evaluation course sufficient or not?

A cross-sectional survey model was used in the study. Fraenkel, Wallen, and Hyun (2014) stated that in this model, the data collection process takes a short time and the data are collected at once. Özdemir (2014) stated that in this survey model, the characteristics of the investigated phenomenon are described as they exist. In this study, this model was preferred because the data were collected in a short time and at once. The study group of the research consists of 241 prospective teachers who are studying at the education faculty of a state university. The study group of the research was determined according to the criterion sampling method. In the study, personal information form and "Attitude Scale towards Measurement and Evaluation" developed by Arastaman, Ylldırım, and Daşçı (2015) were used. The data of the study were collected in the spring semester of the 2019-2020 academic year between 2-13 / 03/2020. Independent samples t-test, descriptive statistics and one-way analysis of variance (ANOVA) were used to analyze the data.

As a result of the research, it was determined that the attitudes of prospective teachers towards measurement and evaluation are at "high" level. This result is considered as an important result of the research. Because, prospective teachers attitudes towards measurement and evaluation suggest that they will apply measurement and evaluation tools in a qualified manner when they start their duty. As a result, the problems experienced in the measurement and evaluation in Turkey can be minimized. Therefore, this result of the research is promising for the future. In the study conducted by Aslan (2019), it was found that the prospective teachers knowledge about complementary measurement and evaluation was sufficient. In the study 
conducted by Karaman and Şahin (2014), the assessment-evaluation literacy levels of prospective teachers were found to be low. In the study conducted by Çalışkan and Yazıcı (2013), it was determined that social studies teachers' attitudes towards measurement and evaluation are low. In addition, while a significant difference was found between the attitudes of prospective teachers towards measurement and evaluation, among the variables of gender, department of education, types of university entrance points and finding the assessment-evaluation course sufficient, no significant difference was found in terms of the grade level of education and academic achievement variables.

Based on the results of the research, the following suggestions can be made:

1. Comparative studies can be conducted between prospective teachers and teachers' attitudes towards measurement and evaluation.

2. In the study, a significant difference was found between the measurement and evaluation attitudes in favor of the prospective teachers studying in classroom and science teaching. The reasons for the low attitudes towards measurement and evaluation in other sections can be investigated.

3. In the study, it was found that the prospective teachers finding the assessment course as sufficient had a significant positive effect on their attitudes towards measurement and evaluation. Instructors who teach this course in teacher training programs will effectively organize the teaching environment and give this course, which will contribute to the positive development of the attitude towards measurement and evaluation.

\section{Kaynakça / References}

Arastaman, G., Ylldırım, K., ve Daşçı, E. (2015). Ölçme ve değerlendirme ölçeğinin geliştirilmesi: geçerlilik ve güvenirlik çalışması. Pamukkale Üniversitesi Eğitim Fakültesi Dergisi, 38, 219-228.

Aslan, S. (2019). Fen bilgisi öğretmen adaylarının tamamlayıcı ölçme değerlendirme ile ilgili görüş̧lerinin incelenmesi. 7. Uluslararası Eğitim Programlan ve Öğretim Kongresi, (9-12/Ekim/2019), Ankara.

Bakırcıŏlu, R. (2016). Ansiklopedik eğitim ve psikoloji sözlüğü. Ankara: Anı Yayıncllk. 
Baykul, Y. (1986). Matematik ve fen eğitimi yönünden okullarımızdaki durum. Hacettepe Üniversitesi Ĕ̆itim Fakültesi Dergisi, 1, 154-168.

Can, A. (2019). SPSS ile bilimsel araştırma sürecinde nicel veri analizi. Ankara: Pegem Yayinclik.

Can, M. F. (2014). Beden eğitimi öğretmenlerinin ölçme ve değerlendirme yeterliliklerine ilişkin alğları: Muğla ili örneği. Yayımlanmamış yüksek lisans tezi. Muğla Sttkı Koçman Üniversitesi, Muğla.

Çalışkan, H., ve Yazıcı, K. (2013). Ölçme ve değerlendirmeye yönelik tutum ölçeğinin geliştirilmesi ve sosyal bilgiler öğretmenlerinin tutum düzeylerinin çeşitli değişkenlere göre incelenmesi. International Journal of Human Sciences, 10(1), 398-415.

Demirel, Ö. (2003). Eğitim sözlüğü. Ankara: Pegem Akademi Yayıncllk.

Fraenkel, J.R., Wallen, N.E., ve Hyun, H. (2014). How to design and evaluate research in education. New York: McGraw-Hill Education.

Green, S. B., ve Salkind, N. J. (2014). Using SPSS for windows and macintosh: Analysing and understanding data. Upper Saddle River, NJ: Pearson.

Ho, R. (2006). Handbook of univariate and multivariate data analysis and interpretation with spss. London \& New York: Chapman \& Hall.

İyilikci, O. (2020). Psikologlar için SPSS ve araştırma desenleri. Ankara: Nobel Yayinclik.

Karaman, P., ve Şahin, Ç. (2014). Öğretmen adaylarının ölçme değerlendirme okuryazarlıklarınn belirlenmesi. Ahi Evran Üniversitesi Kirşehir Eğitim Fakültesi Dergisi (KEFAD), 15(2), 175-189.

Kilıç, R. (2014). Illköğretim 1. kademe öğretmenlerinin otantik ölçme ve değerlendirme yöntemleri ile ilgili bilgi, tutum ve görüşlerinin değerlendirilmesi. Yayımlanmamış doktora tezi. Marmara Üniversitesi, İstanbul.

MEB. (2017). Öğretmenlik mesleği genel yeterlikleri. 02.06 .2020 tarihinde http://oygm.meb.gov.tr/meb_iys_dosyalar/2017_12/11115355_YYRETMEN LYK MESLEYY GENEL YETERLYKLERY.pdf adresinden erişilmiştir.

Mertler, C. A., ve Campbell, C. (2005). Measuring teachers' knowledge and application of classroom assessment concepts: Development of the assessment literacy inventory. Paper presented at the annual meeting of the American Educational Research Association, Montréal, Quebec, Canada.

Newfields, T. (2006). Teacher development and assessment literacy. At presented Proceeding of the 5th Annual JALT Pan-SIG Conference. Shizuoka, University College of Marine Science, Tokai. 
Özdemir, E. (2014). Tarama yöntemi. M. Metin (Edt). Eğitimde bilimsel araştırma yöntemleri içinde (s. 77-97). Ankara: Pegem Yayıncllk.

Pallant, J. (2005). SPSS survival manual: a step by step guide to data analysis using spss for windows. Australia: Australian Copyright.

Seçer, İ. (2015). SPSS ve Lisrel ile pratik veri analizi: Analiz ve raporlaştırma. Ankara: Anı.

Şahin, Ç. ve Karaman, P. (2013). Sınıf öğretmeni adaylarının ölçme ve değerlendirmeye ilişkin inançları. Hacettepe Üniversitesi Eğitim Fakültesi Dergisi, 28(2), 394-407.

Tekin, D. (2019). Sosyal bilgiler öğretmenlerinin ölçme ve değerlendirmeye yönelik özyeterlik algıları ve tutumları arasındaki ilişki. Yayımlanmamış yüksek lisans tezi. Sakarya Üniversitesi, Sakarya.

Tezci, E. (2016). Eğitimde ölçme ve değerlendirme. Ankara: Detay Yayıncılık.

Yıldırım, A. ve Şimşek, H. (2018). Sosyal bilimlerde nitel araştırma yöntemleri. Ankara: Seçkin Yayıncllk.

\section{Kaynakça Bilgisi / Citation Information}

Aslan, S. (2020). Öğretmen adaylarının ölçme değerlendirmeye yönelik tutumlarının çeşitli değişkenler açısından incelenmesi. OPUSUluslararası Toplum Araştırmaları Dergisi, 16(Eğitim ve Toplum Özel Sayıs1), 6047-6068. DOI: 10.26466/opus.755991 